\title{
International Financial Institutions and the Challenges of Global Business Ethics
}

\author{
Henry Kerich ${ }^{1}$ \\ ${ }^{1}$ Professor, School of Business, Strayer University, Washington DC Region, USA \\ Correspondence: Henry Kerich, School of Business, Strayer University, USA. E-mail: kerich75@ gmail.com
}

Received: December 28, 2015

Accepted: January 29, $2015 \quad$ Online Published: February 25, 2016

doi:10.5539/ijef.v8n3p232

URL: http://dx.doi.org/10.5539/ijef.v8n3p232

\begin{abstract}
Business ethics are moral principles and doctrines that determine behavior in the business world. Although the purpose of every business is to earn profits, it also ought to pay a major role in society by ensuring fair practices. Instead of fairness and equality, greed has taken over the present business scenario leading to unethical business practices. World Bank and International Monetary Fund have been criticized for harsh imposition of austerity measures on member borrower countries. IMF programs are connected with adverse social action like reduced investment in public health and education in the recipient countries resulting in ethical violation and lack of corporate social responsibility to the communities served. A number of World Bank financed projects have social and environmental effects for the people in the affected areas resulting in ethical issues criticism. The IMF and World Bank have also been criticized for violation of ethical issues of equity and fair play.
\end{abstract}

Keywords: ethics, financial institutions, values, global, culture, policies, funding

\section{Introduction}

Business ethics are moral values and principles that determine conduct in the business world. Ethics can be applied to all aspects of business starting from creation of an idea to its implementation. While the objective of all businesses is to make profits, it should also contribute to the interest of the society by ensuring fair practices. However, greed has taken over leading to immoral business behaviors. World Bank and International Monetary Fund have been criticized for harsh imposition of austerity measures on borrower countries. IMF programs are connected with adverse social action like reduced investment in public health and education in the recipient countries resulting in ethical violation and lack of corporate social responsibility to the communities served.

Several World Bank programs have social and environmental implications on the people in the affected areas and criticism has centered on ethical matters. A good example is World Bank financed power dam's projects in different countries which have led to the displacement of native people in those areas (Bretton Woods, 2005). The Institutions have also been criticized for violation of ethical issues of equity and fair play in their governance systems which are dominated by developed nations. Most of the time, major decisions and policies are passed and implemented by developed nations without much consultation with developing countries because these nations represent the major donors. The purpose of this article is to examine the business ethical challenges faced by International Financial Institutions with member countries. Some of the ethical challenges faced are moral ethics, virtue ethics, Ethics of care, and deontological ethics.

\section{Global Business Ethical Framework}

The development of a business ethics framework has been developed from basic theories of ethics. Paul (1992) contended that three ethical structures appear to have formed western ethical rational in the last three centuries and these systems are: utilitarianism, natural rights theory, and Kantianism. There has been an attempt to create a primary code of ethics since World War II through the drafting of many international contracts. Some of these contracts are more focused on human rights matters while others address business practices.

A key task in formulating an international business ethics agenda is linking intellectual philosophies and their everyday application. This undertaking of formulating a global ethical structure for organizations is surely a formidable one. The foundations of ethical principles can come from several sources. When the effort is made to create law to affect the ethics of organizations as with the Foreign Corrupt Practices Act in the United States, the consequence can occasionally be contentious and probably unreliable. With the coming up of trading alliances 
like the European Union, the likelihood exists for building a mutual body of law for business ethical practice in a larger region.

The global debate over corporate ethics needs some rules of engagement. The obvious starting point is that companies ought to abide by the laws of the land where they do business (Kapstein, 2001). But these laws are often too weak to protect workers and the environment and this weakness opens the door to legitimate disputes over interpretation and enforcement. When profound differences arise over corporate social responsibility in such areas, the parties involved should set out the advantages and disadvantages associated with adopting higher standards before declaring any proposed policy solution to be the obvious best choice.

\section{Cultural Approaches to Global Business Ethics}

It was pointed out by Weaver (2001) that cultures vary across multiple nations. For example, Japan combines high levels of uncertainty evasion with a collectivist outlook. The high uncertainty evasion might suggest an emphasis on highly formal visible ethics initiatives yet collectivism suggests that direct formal approaches to fostering ethics potentially are problematic. Managers thus will need to make compromises and researchers will need to address the question of how to encourage ethical behavior in organizations under different configurations of cultural characteristics (Weaver, 2001).

A research conducted by Armstrong (1992) reveals that there is a relationship between the cultural environment and the perceived ethical problems. In another study Armstrong finds out the most frequently cited problems of Australian international business managers are gifts/favors/entertainment and that this problems may be related to the culture where the international business is being conducted. In addition, the most important ethical problem to Australian international managers is large scale bribery (Armstrong, 1992). Although, different cultural environments result in different ethical perceptions in international marketing for the sake of ethical consistency, it is necessary to generate internationally applicable ethical rules and regulations.

The World Bank and IMF Institutions are global in nature because they are involved in international transactions extending their structural programs to different countries of the world. These institutions have been highly criticized by the borrowing countries of their impositions of harsh conditionalities. IMF policies are uniform to which it has invited harsh reactions since the member countries have different cultural dynamics.

Although there are moments in which these positive possibilities are acknowledged, they have yet to be pursued in any meaningful way. What is lost in this ethical vision is any real cognizance of the political insinuations of financial restructuring. This idea of ethics as rules of the game in which member states have specific rights and defines moral relations in a historical terms as a series of contractual obligations among equal isolated states. By abstracting from complex historically informed economic and political relationships, this moral vision conceals the power dynamics that characterize financial governance (Best, 2005).

\section{Causes for Failure of Global Business Ethics}

It calls on every business at wherever level they are operating to be morally and ethically right. Doing business in an ethical manner start from the local and domestic fronts and extends to international environments. The corporations that are operating overseas find that understanding and complying with different rules and regulations in other countries, managing employees far from the home countries, serving customers and relating to suppliers and partners in multiple jurisdictions can introduce significant challenges to developing shared ethics in business and values. Having a defined set of companywide global business ethics is a key part of realizing a truly global culture.

In order to succeed in today's evolving global market, organizations must adopt business principles and practices of knowledge sharing, shareholder protection and ethical business practices. Currently, business ethics are considered very important but there are still many organizations that do not engage in ethical behavior. Enron case represents the need of companies to evaluate their business practices from the bottom up in order to design an organizational culture as well as organize the management team that will be committed to the benefit of all stakeholders.

Organizations are more concerned with their bottom-line profits with total disregard to ethical business practices. Utilitarianism advocates for acting in a way that action produce the greatest happiness for everyone (Velasquez, 2012). Corporations can and should strike a balance between maximizing their profits and enriching the welfare to society (stakeholders). Enron is perhaps the most compelling business ethics case in generations. Investors once considered Enron to be the company of the future, but as its demise suggests, it was in reality not a particularly modern business organization especially in its approach to ethics.

As Velasquez (2012, p. 121) noted, "an ethic of care highlights the obligation we have to care for the wellbeing 
of those whom we have close relationships of value, especially those dependent on us". Looking at the above example whereby financial liberalization is not equally distributed in the IMF Institutions and thus ethic of care has not been applied in their transactions. Fair play, equality, and care should not only exist in books, but should also be followed. Because of lack of the right course of action, principles of ethics have been eroded in IMF global business with its members.

The presence of IMF policies in South Africa has led to unjust and unfair practices subjected to the inhabitants there. An ethic of care highlights the obligation we have to care for the wellbeing of those whom we have close relationships of value, especially those dependent on us (Velasques, 2012, p. 121). With the mining degrading the environment and diminishing the prospects for earning a livelihood by other means, IMF action led to the failure of global business ethics and their lack of commitment and intervention in this situation falls short of the Kant's Categorical imperative approach. The approach states that, an action is morally right for a person in a certain situation if the person's reason for carrying out the action is a reason that he or she would be willing to have every person act in a similar situation (Velasquez, 2012). IMF activities have been quite the opposite of this principle.

According to Soederberg (2003), one means of seeing changes by way of imposing neoliberal discipline in the South are through the austerity measures by the World Bank and IMF. Since the 1950s, IMF has relied on conditionalities in its funding. Conditionalities describes conditions in the form of policy implementations that debtor countries must undertake if they are to receive IMF financing. Lately, however, there has been much concern not only about the increase in the actual number of conditionalities, especially over the past decade, but also about their overly intrusive and thus largely ineffective quality. This standardization of corporate governance has resulted in unjust and unfair treatment in form of conditionalities, which directly affects global business ethics.

\section{Conclusions}

Companies that have decided to become truly global ethical organizations must analyze, assess, and amalgamate the heterogeneous legal atmospheres in the nations in which those companies do business. Not only must MNCs recognize and comply with each host country's internal laws, but they must also be cognizant of the pronouncements, policies, conventions, and treaties of the United Nations and various economic and regional trade organizations.

At the minimum International Financial Institutions, should esteem the social and cultural customs of the member countries. Establishing friendships before focusing on the financial matters and understanding divergent perspectives are some of the advice to follow when relating in a global arena. Several businesses identify the significance of establishing relationships around the globe based on mutual respect. One way they assist their employees in this manner is by providing them with a guide to local customs when they visit other nations or meet with foreigners in their home country.

\section{References}

Adams, P. (1992). The World Bank and the IMF in sub-Saharan Africa: Undermining development and environmental. Journal of International Affairs, 46(1), 97.

Armstrong, J. (2001). Economic Imperatives and Ethical Values in Global Business (Book Review). Christian Century, 118(2), 27.

Berenbeim, R.(2006). The Search for Global Ethics. Vital Speeches of the Day, 65(6), 177.

Best, J. (2007). Legitimacy dilemmas: The IMF's pursuit of country ownership. Third World Quarterly, 28(3), 469-488. http://dx.doi.org/10.1080/01436590701192231

Bretton Woods Project. (2005). What are the main concerns and criticism about the World Bank and IMF? Retrieved from http://www.brettonwoodsproject.org

Freeman, R. E. (1994). The politics of stakeholder theory: Some future directions. Business Ethics Quarterly, 4(4), 409-421. http://dx.doi.org/10.2307/3857340

Kapstein, E. B. (2001). The corporate ethics crusade. Foreign Affairs, 80(5), 105-119. http://dx.doi.org/10.2307/20050254

Soederberg, S. (2003). The promotion of Anglo-American corporate governance in the South: who benefits from the new international standard? Third World Quarterly, 24(1), 7-27. http://dx.doi.org/10.1080/713701369

Temkin, L. (2004). Thinking about the needy, justice, and international organizations. Journal Of Ethics, 8(4), 
349-395. http://dx. doi.org/10.1007/s10892-004-4894-2

Velasquez, M. G. (2012). Business ethics: Concepts and cases (7th ed.). Upper Saddle River, NJ: Prentice Hall.

Weaver, G. R. (2001). Ethics programs in global businesses: Culture's role in managing ethics. Journal of Business Ethics, 30(1), 3-15. http://dx.doi.org/10.1023/A:1006475223493

\section{Copyrights}

Copyright for this article is retained by the author(s), with first publication rights granted to the journal.

This is an open-access article distributed under the terms and conditions of the Creative Commons Attribution license (http://creativecommons.org/licenses/by/3.0/). 